\title{
Editorial
}

\section{Publisher's Note: Continued Publication of Cardiogenetics by MDPI}

\author{
Unai Vicario ${ }^{1}$, Franck Vazquez ${ }^{2, *(1)}$ and Shu-Kun Lin ${ }^{2}$ \\ 1 MDPI, Avenida Madrid, 95, 08028 Barcelona, Spain; vicario@mdpi.com \\ 2 MDPI, St. Alban-Anlage 66, CH-4052 Basel, Switzerland; lin@mdpi.com \\ * Correspondence: vazquez@mdpi.com
}

Received: 9 October 2020; Accepted: 9 October 2020; Published: 16 October 2020

check for updates

Cardiogenetics was launched in 2011 and it has been published over the past nine years by PAGEPress Publications [1]. Dr. Giuseppe Limongelli has served as its Editor-in-Chief [2] since its inception and, together with Dr. Lia Crotti, who became co-Editor-in-Chief in 2019, will remain active in this role.

We are delighted to take over the publication of Cardiogenetics from PAGEPress and perpetuate the legacy of this journal, and ensure that we serve well the genetics and the cardiology communities. Cardiogenetics complements very well the MDPI portfolio of medical and life sciences journals $[3,4]$, especially Journal of Cardiovascular Development and Disease [5], Hearts [6], and Genes [7] and strengthen the trans-disciplinary bridge between basic sciences and applied sciences across MDPI journals.

We will publish only one quarterly issue in 2020, and regularly publish four quarterly issues from 2021.

Enjoy publishing your work in Cardiogenetics [8]!

\section{References}

1. Cardiogenetics Homepage at PAGEPress. Available online: https://www.pagepressjournals.org/index.php/ cardiogen/ (accessed on 8 October 2020).

2. Crotti, L.; Limongelli, G.; Antzelevitch, C. Ion channels and beating heart: The players and the music. Cardiogenetics 2011, 1, e1. Available online: https://doi.org/10.4081/cardiogenetics.2011.s1.e1 (accessed on 8 October 2020). [CrossRef]

3. MDPI Medicine \& Pharmacology Journals. Available online: https://www.mdpi.com/subject/med-pharma (accessed on 8 October 2020).

4. MDPI Biology \& Life Sciences Journals. Available online: https://www.mdpi.com/subject/bio-life (accessed on 8 October 2020).

5. Journal of Cardiovascular Development and Disease Homepage. Available online: https://www.mdpi.com/ journal/jcdd (accessed on 8 October 2020).

6. Hearts Homepage. Available online: https://www.mdpi.com/journal/hearts (accessed on 8 October 2020).

7. Genes Homepage. Available online: https://www.mdpi.com/journal/genes (accessed on 8 October 2020).

8. Cardiogenetics Homepage at MDPI. Available online: https://www.mdpi.com/journal/cardiogenetics (accessed on 9 October 2020).

Publisher's Note: MDPI stays neutral with regard to jurisdictional claims in published maps and institutional affiliations.

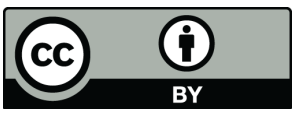

(C) 2020 by the authors. Licensee MDPI, Basel, Switzerland. This article is an open access article distributed under the terms and conditions of the Creative Commons Attribution (CC BY) license (http://creativecommons.org/licenses/by/4.0/). 